\title{
Maritime Spatial Planning and Maritime Archaeology Conservation: Protecting yesterday's legacy by planning for tomorrow, cases from Northern Lebanon
}

\section{Vera Noon}

Beirut; vera.b.n@hotmail.com

\begin{abstract}
Maritime Cultural Heritage (MCH) today stands as a witness of early human naval endeavours. Jeopardized by modern days' maritime activities, $\mathrm{MCH}$ requires a holistic planning approach for conservation management, taking into consideration the future dimension of humankind's maritime aspirations. This need could be incorporated within a Maritime Spatial Planning (MSP) framework, an emerging multidisciplinary process that seeks to prevent conflicts among maritime activities, whilst promoting environmental conservation and sustainable economic development.

This paper identifies main issues related to $\mathrm{MCH}$, and addresses the role that MSP can play in the conservation of $\mathrm{MCH}$, illustrated by two examples from Lebanon.
\end{abstract}

\section{Key words}

Maritime Spatial Planning - Maritime Archaeology - Cultural Heritage - Blue Growth-Multi-scalar approach - Lebanon

\section{Introduction}


Since the dawn of time, humans used the marine environment and its resources for subsistence as the first civilisations thrived on the interface between land and the sea (Yesner et al., 1980). Survival turned into trade, and little by little, humankind's relationship to the sea has shifted. Connecting continents, the Mediterranean trade was a driver for growth since Predynastic times (Mark, 1997), and the Levantine sea basin particularly is a witness of what was always a platform for connectivity, among both cultural and commercial networks (Ashtor, 1983).

Many chronological indicators allow tracing back these ancient civilisations and tracking their expansion throughout time and space, namely archaeological evidence found in situ as well as items found across continents and below the oceans. Shipwrecks in particular have always been a gold mine for archaeologists since studying them allowed connecting the dots between the origin and the destination of the products they carry (Villano, 2009). However, other manmade structures that are not necessarily submerged are equally valuable. For this reason, several definitions related to maritime archaeology have been explored to define the paper's scope of work.

The proposed scope of work for the purpose of this paper is based on interpretations from UNESCO's 2001 Convention on Underwater Cultural Heritage, and based on definitions of marine and maritime archaeology (Cottrell, 1993; Ford et al., 2012; Maritime Archaeology Trust, n.d.; AIMA, n.d.). Thus, Maritime Cultural Heritage $(\mathrm{MCH})$ encompasses tangible and intangible heritage, including coastal, foreshore and submerged remains, possessing a historic, cultural, or archaeological value. (Fig. 1)

While seafaring, trade, and fishing dominated the oceans in the past, today's reality is slightly different. A myriad of maritime activities is taking place in the oceans, all the way to the deep sea, leading to spatial and environmental conflicts (Ehler, 2017). As a result, Maritime Spatial Planning (MSP) emerged, and is increasingly gaining momentum. MSP is a multidisciplinary planning tool, supporting maritime economic development and environmental conservation, while seeking to resolve and prevent conflicts among maritime activities or with the ecosystem. It is both a public and political process, combining bottom-up and top-down approaches (Ehler and Douvere, 2009). A byproduct of the European Integrated Maritime Policy's Blue Growth strategy1, MSP is expected to provide knowledge and ensure a sustainable management of activities at sea, while promoting new maritime economic sectors (European Commission, n.d.).

What effects will an increase in maritime activities have on MCH? Can MSP play a role in the mitigation of potential MCH damage and in producing synergies?

To answer these questions, an assessment of various maritime activities' impacts on $\mathrm{MCH}$ is conducted, followed by a compilation of MSP interventions that can support MCH conservation. Finally, two case studies from Lebanon are used to illustrate the findings, providing case-specific recommendations for $\mathrm{MCH}$ conservation.

\section{Methodology}

1 Blue growth is the long term strategy to support sustainable growth in the marine and maritime sectors. 
This paper is built on three main steps (Fig. 2): Identification of issues related to MCH conservation; compilation of MSP interventions related to MCH conservation; and finally, examination of two Lebanese case studies.

To identify issues related to $\mathrm{MCH}$ conservation, different elements are taken into consideration: the source of the impact (related to human activity); the nature of the impact (direct, indirect); and the location of the $\mathrm{MCH}$ (coastal, foreshore or marine).

As for the different MSP interventions, the compilation is based on nested-approach thinking (Fanning et. al, 2013), a common planning methodology adopted in MSP, recommended particularly for small sea spaces (EU MSP platform, n.d. a). As a result, the MSP tools, collected from multiple examples, follow a multi-scalar logic ranging from global to local scales.

The two selected case studies differ in scale, in socio-political context, and in the nature of the MCH. This allows us to explore the different tools MSP has to offer.

\section{Results}

The first section displays the negative impacts caused by different maritime activities and fragmented institutional frameworks. It is followed by a compilation of the potential MSP interventions that can tackle these $\mathrm{MCH}$ issues.

\section{Identifying issues}

In the contextual aspect, among the first obstacles impeding further $\mathrm{MCH}$ knowledge acquisition is the accessibility to the site itself. A large share of UCH remains undiscovered, where deeply layered artefacts cannot be easily predicted, especially in the deep sea and areas beyond national jurisdiction (UNESCO, 2011). Moreover, the spatial distribution of $\mathrm{MCH}$ is heterogeneous where $\mathrm{MCH}$ is encountered in spots and not in areas (Altvater, 2016). These two conditions render locating and hence protecting MCH difficult.

Direct impacts that may damage MCH mainly stem from the growth of maritime activities such as maritime transport, fishing, energy production, resource extraction, and military activities.

Ports and harbour activities related to commercial and/or recreational maritime transport pose threats during their construction phase as well as during their operational phase (Helcom, 2018). Infrastructural works such as dredging and land reclamation directly damage coastal and foreshore archaeological sites, and may change the course of currents exposing previously buried UCH (UNESCO, 2017 a). Other activities such as vessel manoeuvers, anchoring, and ground tackle proved to be harmful to both the seabed as well as the water quality, therefore to archaeological vestiges lying on the sea bottom (Dizon et al., 2013: 269).

As for the fishing sector, not all fishing techniques are necessarily harmful to UCH. Near coastal areas, aquaculture may result in the alteration of the water's chemical composition, hence influencing the preservation conditions of certain sites (Haponiuk, 2015). Deeper in the water column, dynamite fishing (or blast fishing) is a destructive practice, often illegal yet still widespread, and it has proved to cause an increase in the corrosion of shipwrecks (MacLeod et. al, 2011). In coastal and deep sea areas, bottom trawlers' activities often result in the damage of submerged artefacts and disturbance of assemblages (Dizon et al., 2013: 269). 
Somewhat comparable to the maritime transport sector is the energy sector, where activities that take place in the deeper seas are also supported by coastal infrastructure. However energy production requires connections such as oil/gas pipelines and the routing of electrical/telecommunication cables to substations (UNESCO, 2017 b; Karlikowska et. al, 2018). In the oil and gas industry, the construction and operation of industrial facilities can damage coastal and foreshore MCH, whereas drilling for oil wells can directly damage UCH sites (Faulk, 2010). Likewise, offshore wind farm (OWF) structures for wind turbines require the installation of deep foundations affecting UCH directly, and may also alter current dynamics (Defingou et. al, 2019: 121, 163). Extractive industries such as deep-sea mining and sand extraction similarly affect seabed archaeology (UNESCO, 2017 a). Another direct impact to MCH is caused by explosives used during violent conflicts, and unexploded ordinance dumped in the sea (Dizon et al., 2013: 71). The impact of conflicts on terrestrial cultural heritage has been widely explored, particularly in terms of looting and illicit trade in archaeological assets. Yet the case of $\mathrm{MCH}$ is often overlooked, probably due to inaccessibility, and thus to monitoring difficulties.

In contrast, several threats to $\mathrm{MCH}$ arise from socio-political systems and are harder to tackle. For instance, awareness of the importance of $\mathrm{MCH}$ conservation is still lagging: the definition of MCH remains blurry, and the lack of publicly accessible databases and mapping tools further exacerbates this insensitivity. Moreover, there is still a misconception by which $\mathrm{MCH}$ is considered an obstacle to economic development, as opposed to an economic opportunity (EU MSP Platform, n.d.b).

On a global level, discussions about climate change impacts are growing. It has been proven that climate change can lead to the deterioration of many coastal and marine archaeological sites due to sea level rise, erosion, alterations in conservation environment patterns, and even the spread of new animal species and harmful worms (marine borers) (UNESCO, 2017 c). Climate related flooding of buried sites and severe erosion have been documented in three different archaeological sites in the United States (Reeder Myers, 2015).

\section{Pinpointing solutions}

MSP is rather a top-down exercise, and was proven to be a catalyst for administrative and institutional procedures. However, the top-down and bottom-up processes still need to engage with each other. In fact, MSP can also support the planning process by organising participatory and stakeholder engagement in the decisionmaking process (Morf. et. al, 2019).

The first step towards global awareness began in 1982 through the UN Convention on the Law of the Sea (UNCLOS), which defined maritime boundaries and sovereign rights over the sea bed (UNCLOS, 1982). As far as $\mathrm{MCH}$ is concerned, the convention imposed a general duty on states to protect archaeological and historical objects found at sea. It also promoted collaboration between states: coastal states were given jurisdiction over the Territorial Seas $(24 \mathrm{~nm})$ to control traffic in UCH objects, but this does not cover the remaining Exclusive Economic Zone (EEZ) and continental shelf (European Communities, 2009). Complementing the UNCLOS, the 2001 UNESCO Convention on the Protection of Underwater Cultural Heritage prioritizes in situ preservation of $\mathrm{UCH}$, and it also defines exclusive rights and responsibilities of state parties over UCH in internal waters, archipelagic waters, and Contiguous Zone (articles $7 \& 8$ ). The protection of UCH as well as the reporting and notification measures were addressed in regards to the EEZ and Continental 
Shelf (art. $9 \& 10$ ) but also beyond those zones, in what is referred to as "the Area" (art. $11 \& 12$ ). Coordinating and consulting states collaborate over issuing authorisations for maritime activities and for conducting research related to UCH. This is done with the consent of the flag states and of the states to which the objects pertain by virtue of their cultural/historical or archaeological origin (UNESCO, 2001). (Fig. 3)

MSP is complementary to the above-mentioned principles through two of its main pillars: transboundary MSP (TMSP) and cross border cooperation. Findings have shown that TMSP can be beneficial to cultural heritage management as it encompasses several state countries, and collaborating might bridge the gaps in their fragmented institutional governance (Soininen and Hassan, 2015). In fact, in 2017, UNESCO's Intergovernmental Oceanographic Commission (IOC) and the EU adopted a joint road map to accelerate MSP processes worldwide and promote, among other priority actions, TMSP and sustainable Blue Economy. Two pilot projects are ongoing in the western Mediterranean and southeast Pacific, promoting capacity building and spreading awareness about ocean governance matters. Cultural heritage could be one of the topics of future pilot projects (MSPGlobal, 2019).

An example of regional collaboration is BalticRIM, a project focusing on the relationship between MSP and $\mathrm{MCH}$ in the Baltic Sea. It aims to improve the capacity of regional $\mathrm{MCH}$ planning agencies through innovative public participation methods (submariner network, n.d. a). It also developed three pilot projects on different scales, serving as concrete exercises for planners and stakeholders (submariner network, n.d. b).

A different regional (or even national) tool, complying with the in situ preservation principle, is related to Marine Protected Areas (MPA) establishment. MSP and MPAs have a special bond since initially, parties were interested in developing MPAs as a response to the degradation of marine areas due to human activities (Olsson et. al, 2008). With time, MPAs became more specialised, and began adapting their legal instruments to protection needs. Papageorgiou (2018) listed forms of MPAs recognising not only environmental value of marine sites, but also their cultural and aesthetic values: the International Maritime Organisation's Particularly Sensitive Sea Areas (PSSAs) define maritime transport routing measures to protect ecologically and culturally sensitive areas (IMO, 2019). The UN Environment's Mediterranean Action Plan SPA/BD Protocol promotes the establishment of Specially Protected Areas of Mediterranean Importance (SPAMI) for the conservation of areas of cultural, aesthetic, archaeological, historical, and educational interest (RAC-SPA, n.d. a). Such MPAs are important from a strategic planning point of view as they create synergies between environmental protection and $\mathrm{MCH}$ conservation. It has been proven that common interests were established among archaeologists and environmental protection agencies (Zwick, 2019) despite occasional clashes recorded due to intrusive excavation techniques (UNESCO, 2012).

From synergies to collocation and multiuse, these two planning strategies are applicable on regional and national scales. Identifying opportunities between $\mathrm{MCH}$ sites and new sectors can prove to be beneficial for both sides: activities such as diving trails in UCH sites or virtual UCH tours can provide sources of funding for MCH by diversifying tourism offerings (Przedrzymirska et al. 2018). In the Netherlands, the ban on ship passages within

2 The Area, according to the UNCLOS, is the seabed, ocean floor, and subsoil beyond the limits of national jurisdiction. 
a natural protected marine park has helped preserve wreck locations (EU MSP Platform, n.d. b). Likewise, the protection of submarine cables requires bans on activities like bottom trawling and dredging, which can help protect UCH in return (Haponiuk, 2015: 11).

On a national level, marine licensing and legislative measures can play a major part in the reduction of harmful marine activities, and thus in the regulation process. For instance, some activities used in the process of archaeological exploration require a marine license or a special permission system (Historic England, 2015; Gdansk Maritime Institute, 2016).

Considering land-sea interaction in the planning approach involved integrating $\mathrm{MCH}$ protection policies in land planning processes and Integrated Coastal Zone Management (ICZM) (Khakzad et. al, 2015), such as the case of Scotland (Legislation.gov.uk, 2014).

A global issue, several programs have been designed to mitigate climate change damage to archaeological sites at the national scale (Reeder-Myers, 2015). As far as MSP is concerned, climate change adaptation remains among its top priorities, and several projects introduced it in their planning processes (Santos et al., 2016).

National scale planning sets the stage for a more advanced analysis. However, implementation proves to be more efficient on a local level, particularly through pilot projects. For this reason, place-based planning is the next step in the process.

Zoning is one of the main tools that help resolving spatial conflicts among maritime uses by reducing or prohibiting certain activities. Just like in land-use planning, conflicts can be mitigated by developing a marine cadastral register coupled with zoning regulations as a first step to avoid future overlaps in highly anticipated maritime uses, and a step towards better marine space governance (Suárez de Vivero et. al, 2009). It assigns rights, responsibilities, and restrictions in the marine environment on a sub-national level (Balla and Wouters, 2017). Another form of zoning is the archaeological protected zone or cultural zone, such as in Cyprus (Republic of Cyprus MFA, 2019). Establishing buffer zones near and around offshore structures can generate a similar effect (Defingou et al., 2019).

Vertical zoning is currently being tested, whereby certain activities are restricted near the seabed while allowing others in the water column or on the surface. This can be of particular interest for $\mathrm{MCH}$ as most of the vestiges lie on the seabed (Carr, 2019).

On a local level, most of the MSP tools aim to build bridges between the scientific community and the public. Technological advances in digital modelling and 3D visualisation shed the light on a world otherwise unknown, helping in sharing knowledge and raising awareness about MCH importance (Dizon et al., 2013: 80). The next step after producing this data is sharing it: open data portals and web-GIS services generate interactive maps representing different maritime themes, putting $\mathrm{MCH}$ into perspective by overlaying it with all sorts of information (Fowler et. al, 2010). Cyprus' MSP portal offers thematic maps, conflict maps, and cumulative impacts, allowing for a multidisciplinary view of the marine space (mspcygr, 2014). To take it further, these portals can be participatory, where stakeholders can upload their own data, and it can be used as a platform to exchange ideas and innovative solutions (Eythorsson and Thuestad, 2015). Interactive communication tools and 
visual arts can be even applied in storytelling, such as the example of the Barra Sea (mappingthsea. n.d.). In summary, with proper planning and the right tools, several conflicts can be mitigated.

\section{Discussion}

Lebanon's maritime history stretches back across millennia, with a legacy dating from the Bronze Age. Its seaports were renowned across the Mediterranean and beyond, with moles, forts, and shipwrecks standing as reminders of the maritime journey of its people (Semaan, 2014). Although Lebanon ratified the UNESCO 2001 convention in 2007 (UNESCO, n.d.), it still lacks a national strategy for the conservation of MCH. Existing maritime policies are sectorial, with outdated and poorly implemented frameworks. On an institutional level, the ministries lack cooperation mechanisms with other stakeholders, leading to overlaps or gaps in responsibilities (IMP-MED, 2018).

More specifically, the north of Lebanon has been under the microscope throughout the past decades as it has been subject to several armed conflicts, such as the 2007 Nahr al-Bared war. Tensions began even prior to the Syrian crisis, as the region has been socially and economically marginalised for a long time (Van Der Molen and Stel, 2015: 13). However, the neighbouring Syrian war ignited further violent events around Tripoli, exacerbated by socioeconomic tensions (Lefevre, 2014). Today, as the Syrian conflict nears its end, Tripoli is back in the headlines: this time, it is expected to receive a share of the post-war reconstruction maritime traffic of Syria (RoL/OEPT/DAH, 2017).

How did these conflicts affect the MCH? Will the surge in maritime traffic impact MCH? For the purpose of this paper, it is not necessary to dive in the archaeological details of the sites, but it is, rather, sufficient to understand their protection status and their spatial extent, as well as the current and future maritime activities of both study areas, in order to scan potential conflicts and plan for solution. (Fig. 4)

\section{Nahr al-Bared and Orthosia}

The first case study is a coastal site straddling between the Akkar and North Lebanon Governorates. The Akkar plain stretches seawards to form the widest continental shelf in the country (Sachi and Dimech, 2011: 12; GoL/CDR, 2004). (Fig. 5)

The context of this case is quite peculiar, yet not uncommon in a country such as Lebanon. In 2007, deadly clashes erupted in the Nahr al-Bared Palestinian refugee camp (International Crisis Group, 2012). Later in 2009, as military bulldozers were clearing rubble from the camp, they came across some granite columns. These are now believed to be evidence for the location of the ancient city of Orthosia, which probably dates to the 3 rd millennium BC (Farchakh Bajjaly, 2011). The speculated maritime town might have been an established local or even regional landing site. There is also evidence of coastal quarries slightly southwards (Safadi, 2014; Carayon, 2008 cited in Semaan, 2014: 86). For these reasons, the debate on whether to rebuild the refugees' homes or to protect the valuable archaeology became a controversial issue (Farchakh Bajjaly, 2011). Eventually,

the Lebanese Directorate General of Antiquities (DGA) undertook salvage excavations prior to the reconstruction of the camp (Semaan, 2014: 84). 
Today, life in the camp is almost back to normal. Other activities in this region mainly revolve around the fishing sector. Slightly northwards, the Aabde fishing port is one of the largest in the region. It is even reported that an aquaculture facility used to be active in the port (European Commission, 2011; Doumani, 2007: 49). On another note, cases of dynamite fishing have been reported in this area, with little to no law enforcement (S. Annous 2018, personal communication, 24 February).

The fragmentation of responsibilities in such a small marine space render monitoring illegal activities quite difficult. First of all, the site is lying on the banks of the river that separates the Northern Governorate from the Akkar Governorate, resulting in major obstacles on an institutional level. In Lebanon, there is a myriad of ministries responsible for different aspects of the same maritime activities, and other local authorities in charge of implementation. As a result, governance-related conflicts often arise (MRCZM-IOE-UOB, 2014). In similar cases, MSP can provide a communication platform joining the different stakeholders over a common goal, to set policies through an integrative approach, where authorities, scientists, residents, and marine users can raise issues and negotiate potential solutions together.

An outlook towards the future requires addressing the sensitive political context where the outcome of the Palestinian camp, which is governed by the Palestinian Liberation Organisation3, is linked to the PalestinianIsraeli conflict (International Crisis Group, 2012). In such cases, where MSP has little authority, scenariobuilding tools may be applied to support the decision making process (Mc Gowan et. al, 2019).

Akkar's wide continental shelf suggests easy accessibility, so it can be assumed that there is a high probability of finding objects with archaeological value off coastal sites (Gdansk Maritime Institute, 2016). In this case, the land-sea interaction dimension in the planning process is key. Proposing a marine buffer area extending from the coastal site to the sea, or defining an Archaeological Protection Zone with the help of professionals, can help protect the area from future activities, and can also be used as an exploration lab for scientists to conduct research and develop their knowledge.

\section{Tripoli}

Tripoli, the second largest city in Lebanon, has a rich and diverse terrestrial, insular, and marine cultural heritage (Semaan, 2014: 104-120). Late Bronze Age and Iron Age artefacts are revealed within El Mina's harbour in 1973. Unfortunately the expansion of the port has damaged the remains (Amadouny, 1973). The presence of a submerged mole was also noted, marking the location of the ancient port (Viret, 1999-2000 cited in Semaan, 2014: 104). In fact, and throughout history, Tripoli had one of the major ports of the Levant, but the dislocation of the Ottoman Empire in the dawn of the 20th century marked the beginning of a new chapter (UNESCO, 1954). Tripoli yielded its historic trade centre role to the capital Beirut, but this might soon change (IDAL, 2017). (Fig. 6)

The city's surrounding waters are dotted with a series of islets, stretching over $5 \mathrm{~km}$ seawards. These islets were thought to be used as anchorage spots in antiquity as they protected against dominant winds and currents. Additionally, two shipwrecks are currently lying on the seabed: the HMS Victoria vertically standing between

${ }^{3}$ Lebanese Army and security forces do not have legitimate power within the Palestinian camps. 
75 and 146 meters, sunk in 1893 and the French torpedo carrier sitting some 60 meters below water, sunk in 1941 (Noshie, 2006). Although the latter hasn't been submerged over than 100 years, it can still be considered as a valuable WWII 'heritage assets' (Firth, 2018: 8).

Three of these offshore islands were declared a Marine Protected Area in 19924, called the Palm Islands Nature Reserve (PINR), also classified as a Ramsar site of International Significance (Ramsar, 2016), and are on the SPAMI list (RAC-SPA, n.d. b). Besides their environmental importance, the islands are known for their several cultural heritage sites (MoE/UNDP/LU, 2004). The Palm Island hosts late Roman and medieval period vestiges, as well as crusader structures re-using Roman architectural elements (Salame-Sarkis, 1980 cited in Semaan, 2014: 112). Ramkin Island is also referred to as Fanar Island due to its abandoned lighthouse built circa 1864_(Russ Rowlett and University of North Carolina, 2019). Finally, Bakar Island5, the nearest to the coast, possesses traces of stone quarries and two sea walls (Viret 1999-2000 cited in Semaan, 2014: 110-111). Today it is more commonly referred to as Abd el Wahab Island, named after the family that has been practicing traditional boat construction for years (Kayyal et. al, 2014: 50). (Fig. 7)

Shipping activity has had its toll on the marine environment: the Health and Environment Department of the port authority identified high levels of air and water pollution due to ship emissions, sewage discharge, and cargo transport (namely coal transport and combustion) likely due to the inauguration of new coal storage areas in 2011 (Merhaby et. al, 2015; Tamer, 2013: 117). Another major source of marine pollution near the harbour is the open dump bordering the Abou Ali River estuary (MoE/EU/UNDP, 2014: 39; Lavaill and Clamagirand, 2010: 42). As previously stated, these pollutants may lead to MCH degradation.

Future trends point towards increased maritime traffic linked to the post-conflict reconstruction of Syria, with Tripoli's port expected to receive 20\% of the reconstruction traffic (RoL/OEPT/DAH, 2017: 30). As a result, investments for the port's expansion are pouring in from China, the EU, the Islamic Bank and United States Agency for International Development (USAID) (A. Tamer, 2017, personal communication, 24 August). This will increase maritime traffic near the islands (MarineTraffic, 2019).

Interventions should include urban planning considerations for port construction, to make sure land reclamation and dredging activities are not affecting existing or potential heritage resources. Land use planning needs to also consider marine pollution impacts resulting from waste management failure and sewage discharge. In regards to the sea space, anchoring points need to be reviewed by underwater archaeologists to make sure activity is not affecting valuable assets on the seabed. Concerning navigation activities, specific guidelines need to be set by the port authority, in collaboration with the army. To push it even further, a PSSA can be set to protect both the MPA and the seabed around it.

Moreover, a study of Tripoli municipalities showed that amelioration of the political situation will bring about demographic growth (Lavaill and Clamagirand, 2010: 44) likely coupled with tourism growth. In fact, diving and recreational boating activities near the islands have increased during the past few years: guided tours, diving trails, and boat trips are on the rise (G. Jaradi 2018, personal communication, 11 November). In this case, human

\footnotetext{
${ }^{4}$ The three islands are: The Palm Island, Ramkin Island and Sanani Island.

5 Bakar Island is not part of the PINR
} 
pressure causing increased impacts on the MPA must be mitigated, as trampling proved to have detrimental effects on heritage especially in protected areas (Davenport and Davenport, 2016: 243). Fuel emissions and anchoring need to be monitored as well.

For this purpose, an integrated tourism management plan can help organise marine activities by enforcing boating, fishing, and even research licences. Such an integrated plan can also reduce harmful activities by using vertical zoning. It can alleviate pressures by setting a carrying capacity limit, and minimise overall negative impacts in the long run by keeping a regular monitoring record. Repurposing the existing lighthouse on Ramkin Island can be a potential for Blue Growth, offering educational/recreational services for visitors, as well as a space for monitoring stations: synergies are thus achieved between cultural and economic goals.

Throughout the whole process, the municipality's responsibility is to supplement these policies by organising regular community meetings to spread awareness and inform the locals about new measures through online portals, signage, local gazettes, etc.

Although the fishing sector remains limited to small scale and artisanal fisheries (Kayyal et. al, 2014: 103), MSP must address the potential for fishing to occur in deeper waters using more advanced fishing gear such as trawlers (Firth, 2018: 14). For this reason, while MSP must seek to preserve traditional boat building practices and fishing techniques, it should also aim to enforce existing regulations and develop policies to prevent illegal activities stemming from future spatial competition. In fact, and despite the $500 \mathrm{~m}$ buffer zone around PINR where access and fishing should be restricted for nine months per year (European Commission, 2011), laws and regulations are still not respected, and the islands suffer from dynamite fishing and other forms of illegal activities (S. Annous 2018, personal communication, 24 February), among which is looting (Semaan, 2014). Lastly, the oil and gas strategy planning in Lebanon is currently underway (LPA, 2018). Although drilling won't take place before years to come, spatial conflicts deriving from the activities can be predicted, and hence prevented. For instance, a shipwreck is located within the boundaries of one of the exploration blocks. A buffer zone can be set around that shipwreck, to be registered and disseminated to relevant authorities. Using data from oil and gas expeditions to explore UCH location can be a synergy where resources are shared among different users of the sea.

\section{Conclusion}

MSP is a multi-step future oriented process. Planning priorities vary according to each case's specific context as there is no 'one size fits all' strategy. However, the planning process must include defining stakeholders, analysing current and future maritime activities, and identifying conflicts and synergies in order to set priorities for the final plan.

Concerning $\mathrm{MCH}$, activities that damage coasts and seabed by direct mechanical action can be managed, along with activities altering the chemical and physical context of the sites. Main solutions revolve around either protecting the site itself from surrounding activities, or managing maritime activities around the site. 
In the case of Nahr el-Bared, threats stem from the absence of protection mechanisms and the sensitive and volatile political context, therefore scenario analysis coupled with precautionary protection measures was the go-to strategy.

In the case of Tripoli, where multiple activities are taking place near a protected area, interventions are rather sectorial where behaviour of marine space users can be monitored, and where existing environmental protection measures and tourism activities can be combined with cultural heritage site protection.

Recommendations provided are indicative and future research is required to develop a concrete maritime spatial plan. However, the structural aspect of the paper sets the stage for other case studies that share common issues: one can draw parallels between the Nahr el-Bared camp case in the north and the Rachidie camp in the south of Tyre, where archaeological artefacts have also been unveiled below the coastal refugee camp (Doumet Serhal, 1982). Likewise, Sidon's historic port, its islets, and the impact of its expansion on its cultural heritage are comparable to the case of Tripoli (Marriner et. al, 2008).

The challenge today is using valuation techniques to prioritise the topic of $\mathrm{MCH}$ for both the public and the private sectors, in order to later incorporate it in the growing regional Blue Growth trends (Claesson, 2011). With the wide array of planning tools MSP can offer, along with technological advances, the remaining obstacle is to achieve political will.

\section{Acknowledgements}

I would like to thank the Honor Frost Foundation for funding my participation in MAGS 2019, particularly Dr. Lucy Blue and Dr. Lucy Semaan. Special regards go to the organisers from Southampton and Oxford universities for their hard work and support. Final thoughts go to friends and colleagues who kindly helped me in the writing process.

\section{References}

AIMA (n.d.), What is Maritime Archaeology? Australian Institute for Maritime Archeology. [Online] Available at: http://www.aima-underwater.org.au/what-is-maritime-archaeology/

Amadouny, Z. E., 1973, Le site archéologique sub-aquatique d'el Mina Tripoli-Liban, Beirut: TransPress.

Amadouny, Z. E., 1999, Plongée archéologique sur le littoral libanais, Beirut.

Ashtor, E., 1983, Levant trade in the Middle Ages. Princeton University Press.

Bailey, G., 2011, 'The Significance of Underwater Cultural Heritage', Department of Archaeology, University of York, United Kingdom. In: UNESCO Scientific Colloquium on Factors impacting the Underwater Cultural Heritage. Royal Library of Belgium, Brussels, Belgium.

Carr, S., 2019, Should we be conserving and managing (MEA) marine ecosystems in 3D? The latest thinking on vertical zoning in Marine Ecosystems and Management, February 9. Available at: https://meam.openchannels.org/news/skimmer-marine-ecosystems-and-management/should-we-beconserving-and-managing-marine-ecosystems 
Claesso, S., 2011, 'The Value and Valuation of Maritime Cultural Heritage'. International Journal of Cultural Property 18.1, 61-80.

Dizon, E., Egger, B., Elkin, D., Erreguerena, P. L., Grenier, R., Gribble, J., Guerin, U., Khalil, E., Manders, M., Maarleveld, T., Memet, J. B., Mesic, J., Nieto Prieto, X., Nutley, D., Pomian, I., Scott-Iretom, D., Trakadas, A., and Veccell, R., 2013, Manual for Activities directed at Underwater Cultural Heritage, Guidelines to the Annex of the UNESCO 2001 Convention, in Arabic. Available at: www.unesco.org/en/underwater-cultural-heritage. Defingou, M., Bils, F., Horchler, B., Liesenjohann T., and Nehls G., 2019, PHAROS4MPAS- A review of solutions to avoid and mitigate environmental impacts of offshore windfarms. BioConsult SH on behalf of WWF France, 269.

Doumani, F., 2007, Integrated Management of East Mediterranean Coastlines : Northern Lebanon.

Doumet-Serhal, C., 1982, 'Les tombes IV et V de Rachidiyeh' Annales d'histoire et d'archéologie de l'USJ. vol 1, 89-148.

Ehler, C. and Douvere, F., 2009, Marine Spatial Planning: a step-by-step approach toward ecosystem-based management. Intergovernmental Oceanographic Commission and Man and the Biosphere Programme. IOC Manual and Guides No. 53. UNESCO, Paris.

Ehler, C., 2017, World-Wide Status and Trends of Maritime/Marine Spatial Planning. Presented at the 2nd International Conference on Marine/Maritime Spatial Planning, UNESCO, Paris.

European Commission (n.d.) Blue Growth - Maritime Affairs - Integrated Maritime Policy [online] Available at: https://ec.europa.eu/maritimeaffairs/policy/blue_growth_en

European Commission, 2011, Exploring the potential of Maritime Spatial Planning in the Mediterranean.

European Communities, 2009, Legal aspects of maritime spatial planning Summary report.

EU MSP Platform (n.d. a) Multi-scalar approach to MSP [online] Available at: https://www.mspplatform.eu/faq/multi-scalar-approach-msp

EU MSP Platform (n.d. b) Marine Cultural Heritage (MCH) and MSP [online] Available at: https://www.mspplatform.eu/faq/marine-cultural-heritage-mch-and-msp

European Parliament and Council (EPC), 2014, Directive 2014/89/EU of the European Parliament and of the council of 23 July 2014 establishing a framework for maritime spatial planning, Off. J. Eur. Union L 257 135145. Available at: https://eur-lex.europa.eu/legal-content/EN/TXT/?uri=celex\%3A32014L0089

Eythorsson E. and Thuestad A., 2015, 'Incorporating Traditional Knowledge in Environmental Impact Assessment-How Can It Be Done?', Arctic Review on Law and Politics, Vol 6 no. 2.

Fanning, L., Mahon, R., and McConney, P., 2013, Applying the large marine ecosystem (LME) governance framework in the Wider Caribbean Region. Marine Policy 42.

Farchakh-Bajjaly, J., 2011, 'Politicians: Assassins of Lebanese heritage, Archaeology in Lebanon in times of armed conflict', in P. Stone (ed.), Cultural Heritage, Ethics and the Military, Heritage Matters 4, Boydell Press: Woodbridge, 189-191. 
Faulk, K., 2010, Deepwater Archaeology in Oil and Gas - The Underwater Blogger; The Museum of Underwater Archaeology [online] Available at: https://muablog.wordpress.com/2010/12/14/deepwaterarchaeology-in-oil-and-gas-by-kimberly-l-faulk-nee-eslinger/

Firth, A., 2018, Managing shipwrecks. Fjordr Limited for Honor Frost Foundation.

Fowler, C., Smith, B. and Stein, D., 2010, 'Building a Marine Spatial Data Infrastructure to support Marine Spatial Planning in U.S. waters'. Geographic Technologies applied to Marine Spatial Planning and Integrated Coastal Zone Management, 1, 46-60.

Gdansk Maritime Institute, 2016, Study of Conditions of Spatial Development of Polish Sea Areas.

Government of Lebanon (GoL)/CDR, 2004, Schéma d'Aménagement du Territoire Libanais Rapport Final. Beirut, Lebanon.

Haponiuk, R., 2015, Underwater Cultural Heritage in the context of Marine Spatial Planning: An integration approach, EMMCMSP.

Helcom, 2018, 'Maritime activities in the Baltic Sea', Doktorarbeit, pp. 1-40.

Historic England, 2015, Accessing England's Protected Wreck Sites: Guidance Notes for Divers and Archaeologists. Available at: https://www.historicengland.org.uk/advice/planning/consents/protectedwreck-sites/

IDAL, 2017, Investment opportunities in North Lebanon 2017.

International Crisis Group, 2012, Lebanon's palestinian dilemma: the struggle over Nahr al-Bared. Middle East Report n 117.

International Maritime Organisation, 2019, 'Particularly Sensitive Sea Areas'. [online] available at: http://www.imo.org/en/OurWork/Environment/PSSAs/Pages/Default.aspx

Karlikowska, M., Makowska, J., Marczak, A., Stryjecki, M., Trzaska, M., Wojcik, M., Przedrzymirska, J., 2018, Impact Mitigation Strategy of the Baltic Offshore Grid, Baltic InteGrid project.

L. مها كيال، د. مارلين حيدر، د. جان توما (2014). البحر وحضره في ثقافة مدينة: Kayyal, M., Haydar, M., Touma, J. 2014 دراسة في ثقافة عيش مجتمع مدينة الميناء اللجنة الوطنية اللبنانية لليونسكو

Khakzad, S., Pieters, M. and Van Balen, K., 2015, 'Coastal cultural heritage: A resource to be included in integrated coastal zone management'. Ocean and Coastal Management. Elsevier Ltd 118, 110-128.

Lavaill, J. P. and Clamagirand, E., 2010, Sustainable development program of the coastal zone Urban Community of Al Fayhaa.

Lebanese Petroleum Administration, 2018, Road map. Available at: https://www.lpa.gov.lb/road\%20map.php Lefevre, R., 2014, The roots of crisis in Northern Lebanon, Carnegie Endowment for International Peace.

Legislation.gov.uk, 2014, Historic Environment Scotland Act. [online] Available at: http://www.legislation.gov.uk/asp/2014/19/schedule/4/enacted

MacLeod, I. D., Richards, Z. T. and Beger, M., 2011, 'The effects of human and biological interactions on the corrosion of WWII iron shipwrecks in Chuuk Lagoon', 18th International Corrosion Congress 2011, 1 (February 2016), 298-309.

Mappingthesea, (n.d.), Barra [online] Available at: http://www.mappingthesea.net/barra/ 
Marine Traffic, 2019, Global Ship Tracking Intelligence, AIS Marine Traffic. Available at: https://www.marinetraffic.com/en/ais/home/centerx:35.8/centery:34.5/zoom:11

Maritimearchaeologytrust, (n.d.), What is maritime archaeology? Maritime Archaeology Trust. [online] Available at: https://www.maritimearchaeologytrust.org/whatismaritimearchaeology

Mark, S., 1997, From Egypt to Mesopotamia, Texas A\&M University Press.

MCR/IOE/UOB, 2012, Artificial reef of Aabde, Northern Lebanon, July 2012.

Merhaby, D., Net, S., Halwani, J., and Ouddane, B., 2015, 'Organic pollution in surficial sediments of Tripoli harbour, Lebanon', Marine Pollution Bulletin. Elsevier Ltd, 93.1-2, 284-293.

Millenium Ecosystem Assessment, 2005, Ecosystems and human well-being: Synthesis. Island Press (Vol. 5), New York.

MoE/UNDP/LU 2004, Final Report: Biodiversity Assessment and Monitoring in the Protected Areas. Palm Islands Nature Reserve.

MoE/EU/UNDP 2014, Lebanon Environmental Assessment of the Syrian Conflict and Priority Interventions. Available at: http://www.undp.org/content/dam/lebanon/docs/Energy and Environment/Publications/EASCWEB.pdf

Morf, A., Kull, M., Piwowarczyk, J. and Gee, K., 2019, ‘Towards a ladder of Marine/Maritime Spatial Planning participation' in K. Gee and J. Zaucha (eds.) Maritime spatial planning: past, present, future. Palgrave Macmillan, 210-244.

MRCZM-IOE-UOB, 2014, Legal assessment and recommendations report. National Consultancy for the Identification of Legal, Policy and Institutional Gaps and Policy Reforms Drafted for Marine and Coastal Biodiversity Protection.

Mspcygr, 2014, Conflict maps [online] Available at: http://www.mspcygr.info/\%CF\%87\%CE\%AC\%CF\%81\%CF\%84\%CE\%B5\%CF\%82-

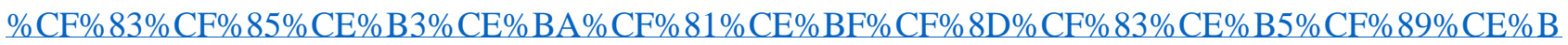
$\mathrm{D} /$

MSPGlobal, 2019, Marine Spatial Planning global [online] Available at: http://www.mspglobal2030.org/ Noshie, W., 2006, Tales and Dives in Lebanon [online] National Institute for Scuba Diving (NISD), 15 October 2006. Available at: http://www.nisd-online.com/article-101506-talesanddivesinlebanon.htm Olsson, P., Folke, C. and Hughes, T. P, 2008, 'Navigating the transition to ecosystem-based management of the Great Barrier Reef', Australia. Proceedings of the National Academy of Sciences 105.28, 9489-9494.

Przedrzymirska, J. and Zaucha, J., 2018, Multi-use Concept in European Sea- basins, Edinburgh: MUSES Project.

RAC-SPA (n.d) SPAMIs. [online] Available at: http://www.rac-spa.org/spami

RAC-SPA (n.d. a) SPA/BD Protocol. [online] Available at: http://www.rac-spa.org/protocol

Ramsar, 2016, The List of Wetlands of International Importance. Ramsar, 14, 1-48. 
Reeder-Myers, L. A., 2015, 'Cultural Heritage at Risk in the Twenty-First Century: A Vulnerability Assessment of Coastal Archaeological Sites in the United States'. Journal of Island and Coastal Archaeology, 10.3, 436445.

Republic of Cyprus, Ministry of Public Affairs, 2019, Underwater Cultural Heritage [Online] Available at: http://www.mfa.gov.cy/mfa/mfa2016.nsf/mfa87_en/mfa87_en?OpenDocument

RoL/OEPT/DAH, 2017, Update of Tripoli port long term development scheme - Draft final feasibility reportAugust 2017.

Russ, R. and the University of North Carolina, 2019, Lighthouses of Lebanon. [online] Available at: http://www.ibiblio.org/lighthouse/lbn.htm

Sacchi, J. and Dimech, M., 2011, Report of the FAO EastMed Assessment of the Fishing Gears in Lebanon, (July), 55 .

Santos, C. F., Agardy, T., Andrade, F., Barange, M., Crowder, L. B., Ehler, C. N., Orbach, M. K. and Rosa, R., 2016, 'Ocean planning in a changing climate'. Nature Geoscience, 730.

Semaan, L., 2014, Desk based assessment of maritime archaeological sites on the Lebanese coast.

Soininen, N. and Hassan, D., 2015, 'Marine spatial planning as an instrument of sustainable ocean governance'. Transboundary Marine Spatial Planning and International Law, 3-20.

Suárez de Vivero, J. L., Rodríguez Mateos, J. C. and Florido del Corral, D., 2009, 'Geopolitical factors of maritime policies and marine spatial planning: State, regions, and geographical planning scope'. Marine Policy $33.4,624-634$.

SubmarinerNetwork (n.d. a), Baltic Sea Region Integrated Maritime Cultural Heritage Management [Online] Available at: https://www.submariner-network.eu/projects/balticrim/about-balticrim

SubmarinerNetwork (n.d. b), BalticRIM cases [Online] Available at: https://www.submarinernetwork.eu/projects/balticrim/balticrim-cases

Submariner-network.eu., 2019, About - SUBMARINER Network. [online] Available at: https://www.submariner-network.eu/projects/balticrim/about-balticrim

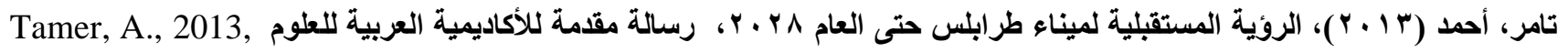
(و التكنولوجيا والنقل البحري للحصول على درجة الدكتوراه في تكنولوجيا النقل البحري (النقل الدولي واللوجستيات.

UNESCO (n.d.) 'States Parties' In: 2001 Convention - Underwater Cultural Heritage. [Online] Available at: http://www.unesco.org/eri/la/convention.asp?KO=13520\&language=E\&order=alpha

UNESCO, 1954, Lebanon suggestions for the plan of tripoli and for the surroundings of the Baalbek acropolis. UNESCO, 2001, About the Convention on the Protection of the Underwater Cultural Heritage. [Online] Available at: http://www.unesco.org/new/en/culture/themes/underwater-cultural-heritage/2001-convention/ UNESCO, 2001, Convention on the Protection of the Underwater Cultural Heritage. Paris, 2 November 2001 [online] Available at: http://www.unesco.org/eri/la/convention.asp?KO=13520\&language=E\&order=alpha UNESCO, 2012, 'Unit 10: Intrusive Techniques in Underwater Archaeology' in Training Manual for the UNESCO Foundation Course on the Protection and Management of Underwater Cultural Heritage in Asia and the Pacific. 
UNESCO, 2017, 'Threats' Underwater Cultural Heritage. Available at: http://www.unesco.org/new/en/culture/themes/underwater-cultural-heritage/about-theheritage/protection/threats/

UNESCO, 2017, Underwater Cultural Heritage. [Online] Available at: http://www.unesco.org/new/en/culture/themes/underwater-cultural-heritage/

UNESCO, 2017b, 'Developing the seabed: resource extraction and energy development at sea' Underwater Cultural Heritage. [online] Available at : http://www.unesco.org/new/en/culture/themes/underwater-culturalheritage/protection/threats/developing-the-seabed/

UNESCO, 2017c, 'Environmental impact and climate change' Underwater Cultural Heritage [online] Available at: http://www.unesco.org/new/en/culture/themes/underwater-culturalheritage/protection/threats/environmental-impact-and-climate-change/

United Nations, 1982, Convention on the Law of the Sea, [Online] Available at: www.un.org/depts/los/convention_agreements/texts/unclos/unclos_e.pdf

Van Der Molen, I. and Stel, N., 2015, 'Introduction: Conflict and Environment in North Lebanon: Vulnerability in a Volatile Socio-Political Context', in Van Der Molen, I. and Stel, N. (eds.), Conflict and Environment in North Lebanon: Vulnerability and resilience from a multi-disciplinary perspective. UOB-University of Twente, $1-20$.

Villano, M., 2009, 'Shipwrecks Offer Clues to Ancient Cultures'. Oceanus Magazine, WHOI, 18 Dec. 2009. Available at: www.whoi.edu/oceanus/feature/shipwrecks-offer-clues-to-ancient-cultures.

Yesner, D,. R., Ayres, W., S., Carlson, D., L., Davis, R., S., Dewar, R., Morales, M. R. G., Hassan, F. A., Hayden, B., Lischka, J. J., Sheets, P. D., Osborn, A., Pokotylo, D. L., Rogers, T., Spanier, E., Turner, B. L. and Wreschner, E. E., 1980, 'Maritime Hunter-Gatherers: Ecology and Prehistory [and Comments and Reply]', Current Anthropology. [University of Chicago Press, Wenner-Gren Foundation for Anthropological Research], 21.6, pp. 727-750. Available at: http://www.jstor.org/stable/2742514.

Zwick, D., 2019, Synergistic effect with environmental protection: Scanning the seabed for anomalities SUBMARINER network - 07 May [online] Available at: https://www.submarinernetwork.eu/projects/balticrim/balticrim-news-2/501-synergetic-effect-with-environmental-protection-goalsscanning-the-seabed-for-anomalies 
Figures

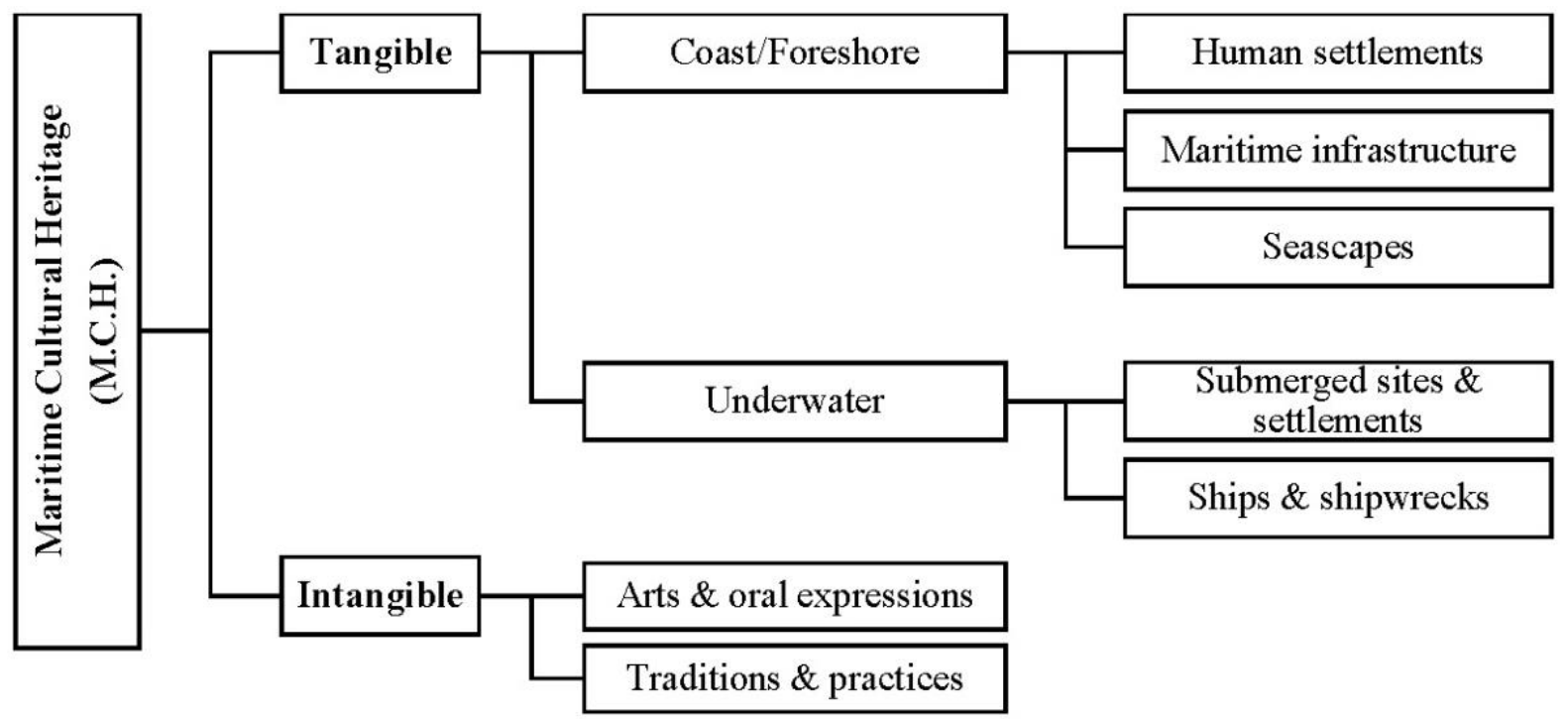

Figure 1: Maritime Cultural Heritage components. (C) V. Noon.

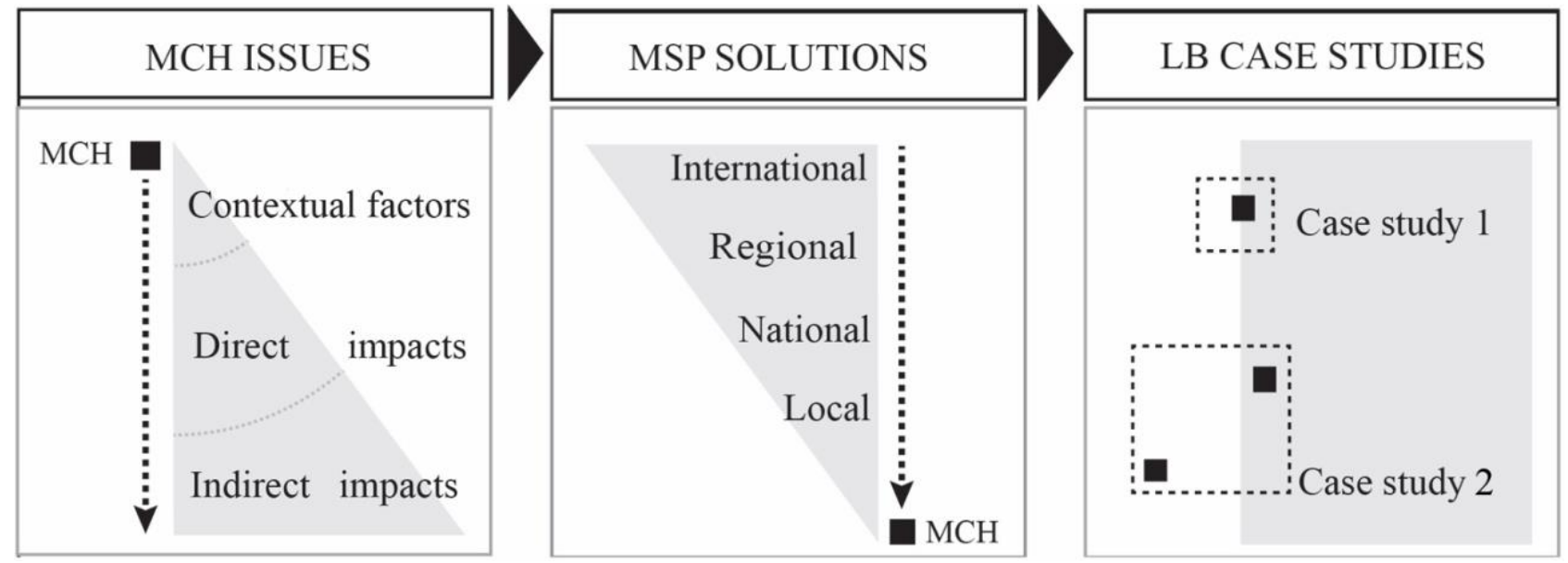

Figure 2: Research methodology. (C) V. Noon. 


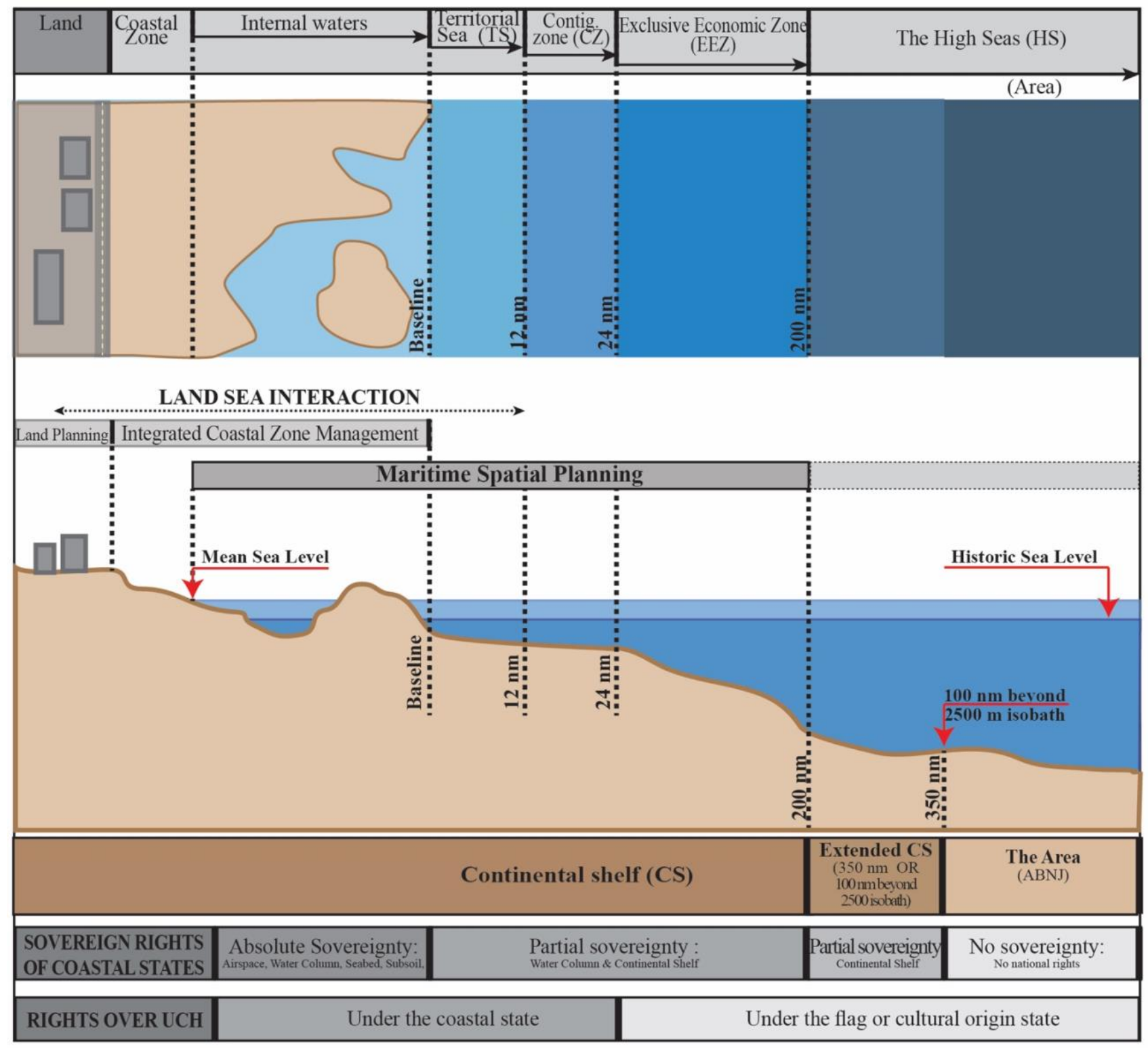

Figure 3: Maritime boundaries, coastal state sovereign rights and jurisdictions over UCH.

(C) V. Noon, based on UNCLOS 1982, UNESCO 2001, and EU MSP Directive 2014. 


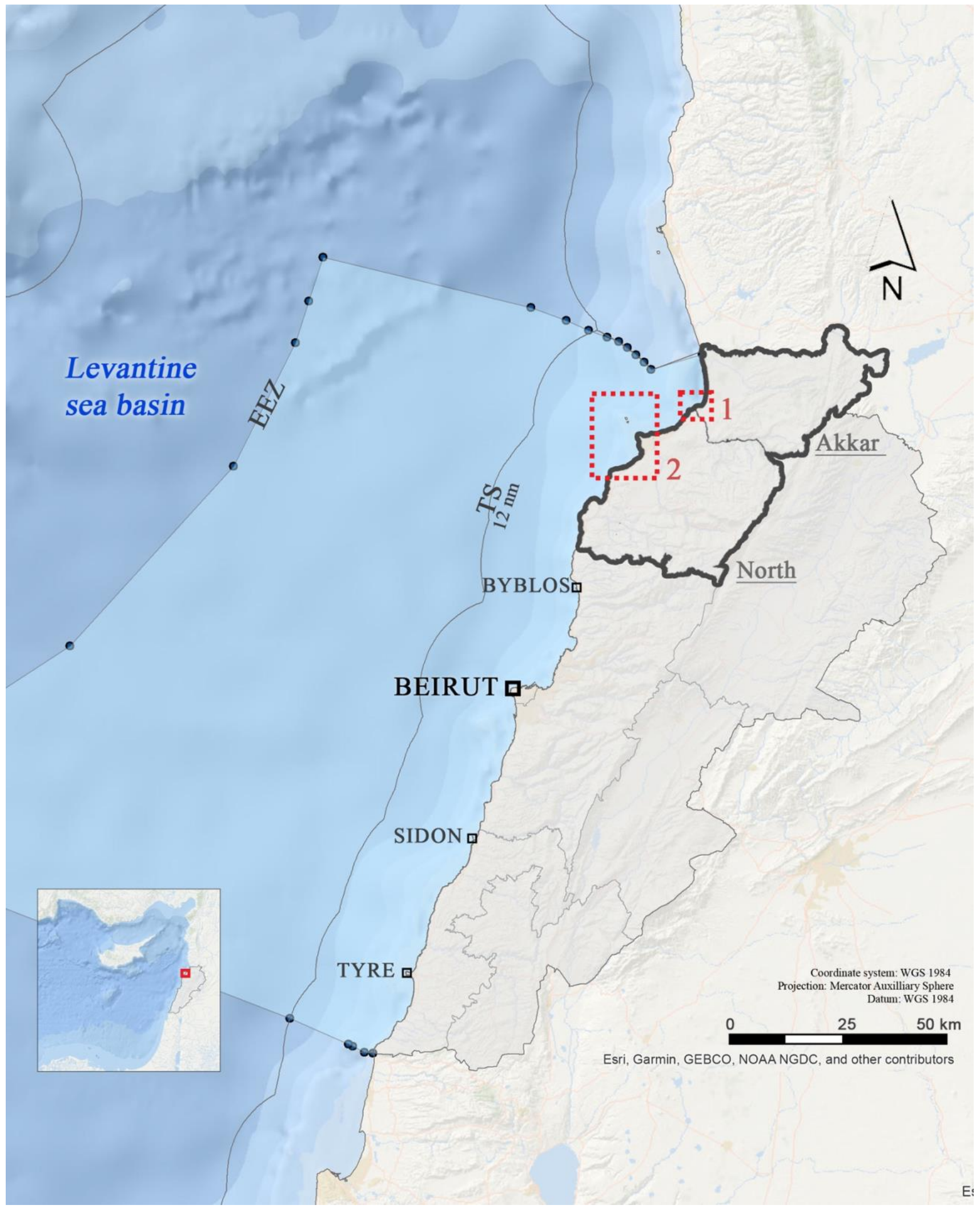

Figure 4: Map of Lebanon with the two case studies: (1) Nahr el-Bared (2) Tripoli. This map shows the Lebanese maritime boundaries along with the major coastal cities. Disputed maritime boundaries are not represented. [TS: Territorial Seas up to $12 \mathrm{~nm}$; EEZ: Exclusive Economic Zone]. () V. Noon. 


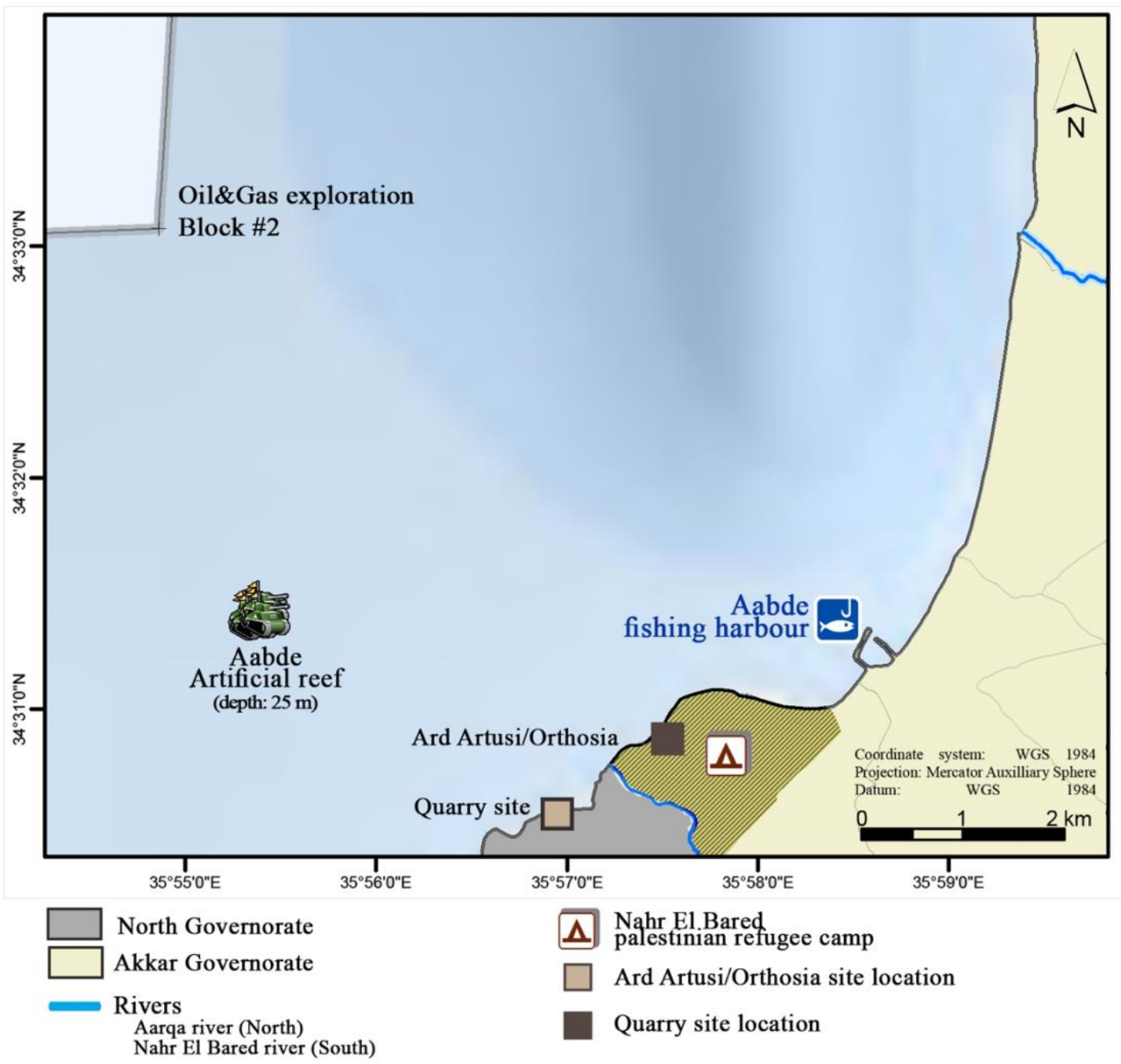

Figure 5: Nahr el-Bared's Palestinian refugee camp and Orthosia's archaeological sites. ㄷ V. Noon. 

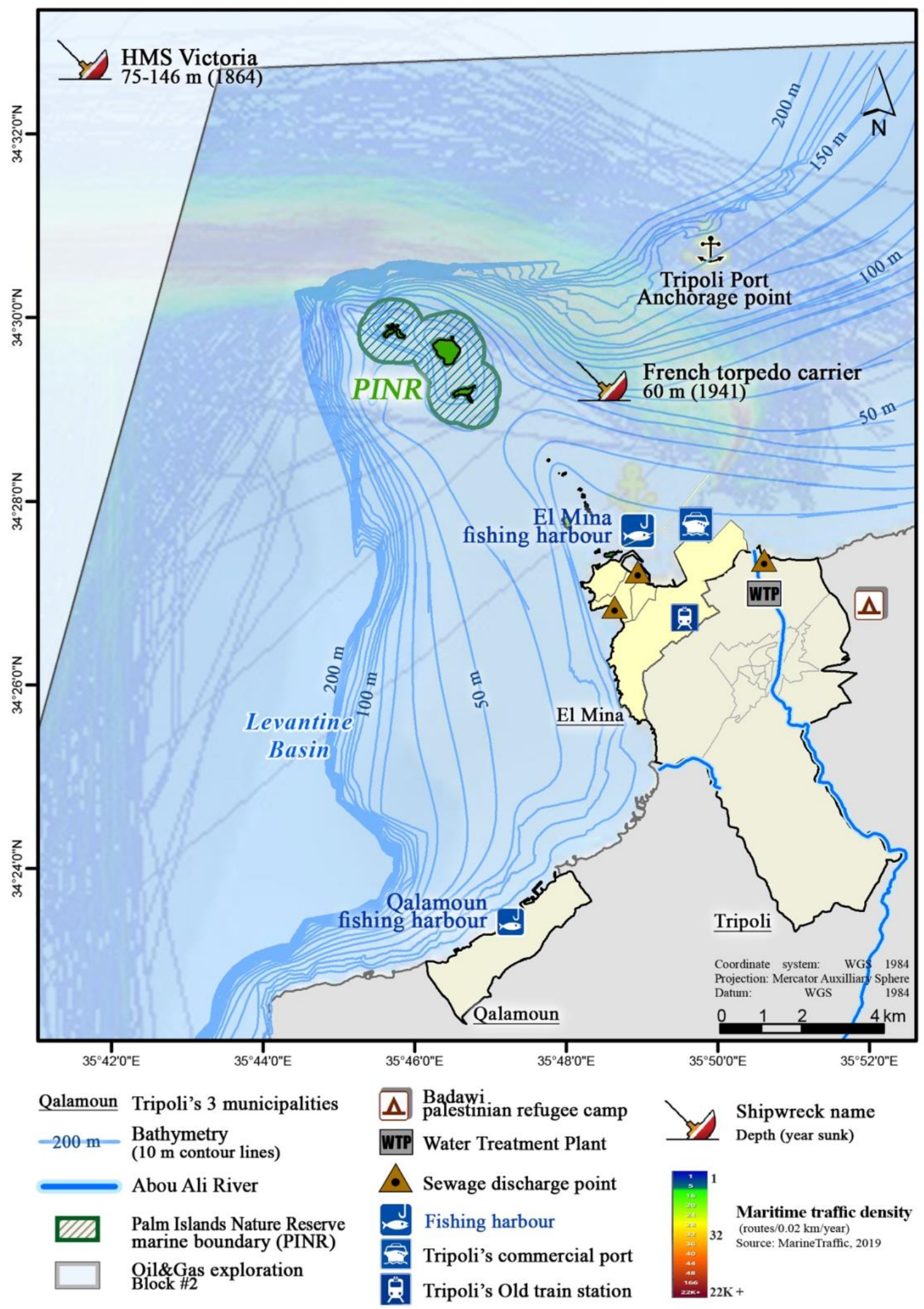

Figure 6: Tripoli and its islets. Tripoli has three municipalities, among which one is physically detached (Qalamoun), posing yet another obstacle for planning maritime activities. Maritime Traffic

Density layer shows intensive activity near both the PINR and the French Torpedo carrier. (C) V.

Noon. 


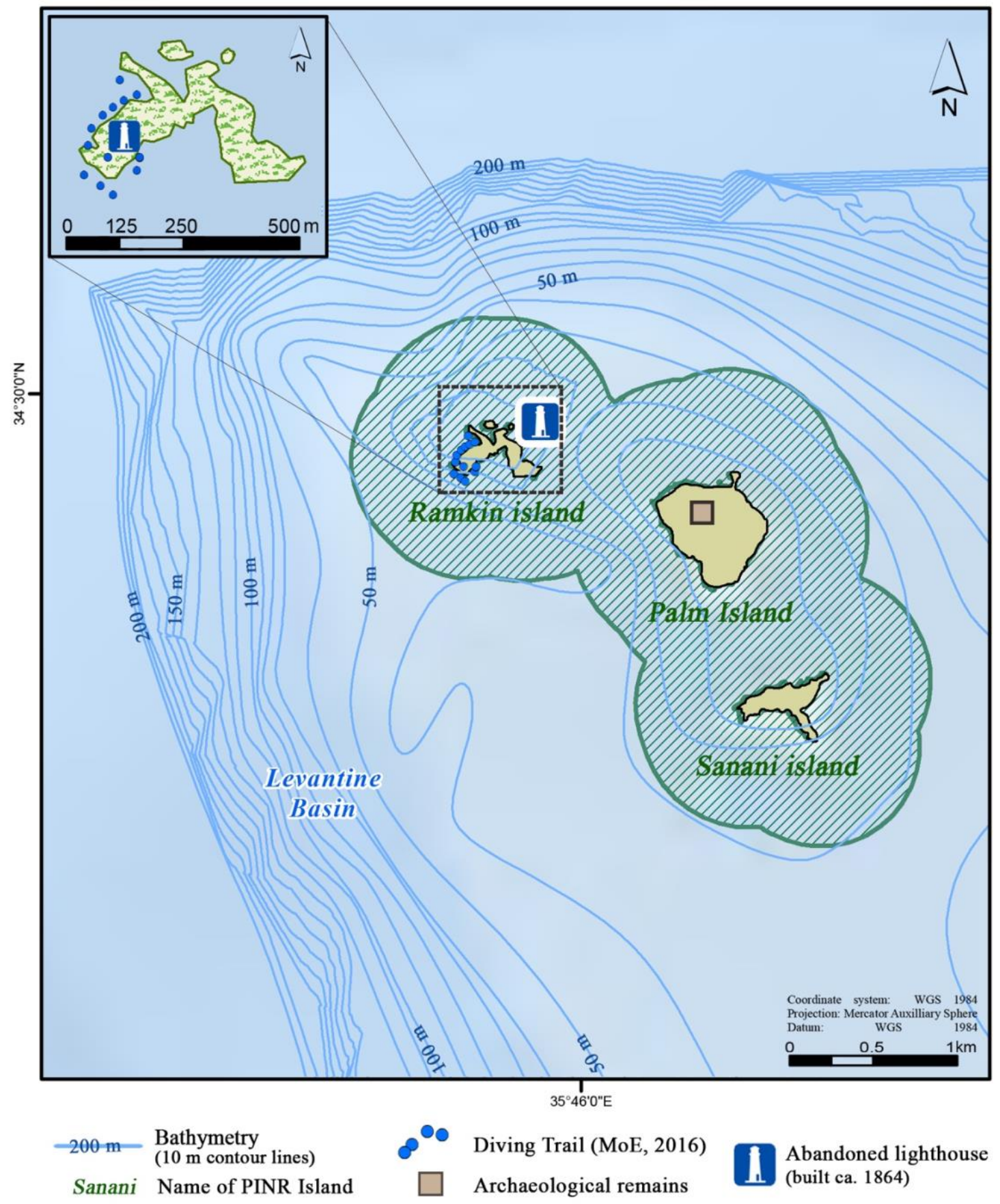

Figure 7: The Palm Islands Nature Reserve and its surroundings. A $500 \mathrm{~m}$ buffer zone is set around the three islands to prohibit fishing and recreational activities nine months per year. (C) V. Noon. 